\title{
Application of the global computing curriculum guidelines and skills frameworks for competency discovery and analysis: a case study of data analytics
}

\author{
Emre Erturk \\ Corresponding Author \\ Eastern Institute of Technology \\ New Zealand
}

\author{
Guozhen Huang \\ First Author \\ CIC Higher Education \\ Australia
}

\begin{abstract}
The current global computing curriculum guidelines including MISI2016, IT2017 and IS2020 are built to promote and facilitate competency-based higher education programs development and to enhance graduate employability. Their applications however are facing challenges in understanding, interpretation and operationalization. Taking data analytics and data engineering, this study shows how these guidelines are used to discover and analyze competencies, the boundaries between typical IT and IS programs and between IS undergraduate and postgraduate programs and further, the gaps for these programs to fill to incorporate professional practice competencies. The global skills frameworks are invoked and SFIA 7 is used to assist analysis.
\end{abstract}

Keywords- Data analytics: data engineering; curriculum guideline; competency-based curriculum; data skills

\section{INTRODUCTION AND THE GENERAL APPROACH}

The current global computing curriculum guidelines including MSIS2016, IT2017 and IS2020 are developed under a great influence by the concept of competency and the efficacy of competency-based approach. The aim is to close the gaps between curricular competencies (developed from fulfilling a curriculum) and professional practice competencies (needed in the industry) to enhance the worth of the computing programs and graduate employability. Their applications however are facing challenges in understanding, interpretation and operationalization. Great insights have been provided in previous studies from different perspectives such as understanding of IT (Information Technology) in the modern age, unpacking dispositions and visualizing competencies [13, $18,24]$. This study is an addition to the efforts.

A domain case is chosen to make the study scope manageable and the output information explicit to inform possible curriculum designs, reviews and revisions. Data analytics is chosen because it is a skillset that is increasingly demanded in the IT job market and an enlarging domain in the computing curricula $[18,23]$. Moreover, it is a domain that is applied by tertiary education institutions variedly and the curricular boundaries between different IT and IS (Information Systems) programs are not clear [15, 25].

This study answers three questions:

1) What are the competencies that are suggested from the global computing curriculum guidelines?

2) How IT and IS programs, undergraduate and postgraduate programs differ in competencies?

3) What are the gaps that need to be filled by the computing programs to incorporate professional practice competencies?

The answers to the first two questions will enable a clearer understanding of the competencies about data analytics, what is included in each of the typical IT and IS curriculum programs, and where their boundaries are. The answer to the third question will clarify the professional practice competencies that are possibly lacked in IT and IS programs, the gaps.

For answering the third question, the global IT skills frameworks including SFIA 7, e-CF 3.0 and SF for ICT are examined. These frameworks prescribe professional practice competencies that are needed in the industry; however, ambiguities, intricacies and variances in these frameworks may make their comparisons and cross-referencing impossible [7, 8]. This issue is resolved by a choice-making.

It is worth reiterating that competencies developed from fulfilling a curriculum are different from competencies that are needed in the industry, the former refers to curricular competencies and the latter, the professional practice competencies [2]. A clear understanding of this difference will help distinguish between what can be achieved in a university setting and what can be acquired through experience in workplace $[14,19]$. This acknowledged, reconciling two streams of competencies will reveal the gaps where IT and IS programs should focus on.

The study starts with reviewing of the concept of data analytics and the concept of competency to prepare the lens for examining the curriculum guidelines. The overall structures, 
rationales, key concepts and competency specifications are then carefully reviewed, and all the relevant competencies relating to data analytics are captured. The understanding and interpretation that are involved in this process are aided by recent (since 2010) studies retrieved from four research databases including Google Scholar, ProQuest, IEEE Xplore and ScienceDirect. The key search words and their combinations that are used include "data analytics", "data analyst", "data analysis", "business analytics" and "data scientist" as one category, and "competency", "competence", "skills", "ability" and "capability" as another.

The curricular competencies for IS and IT programs, and IS undergraduate and postgraduate programs are then compared with each other. Care is taken to ensure competencies that are brought in comparisons are at the same level of abstraction (categorization). Bogging down too much to details may fall the study into the traps of endless exhaustivity, a tendency that is warned by the global educational associations [2, 9]. This process reveals the core competencies that are shared by all the programs, and different competencies (the boundaries) between them.

To discover the gaps between curricular competencies and professional practice competencies, three universal skills frameworks including SFIA 7, e-CF 3.0 and SF for ICT are examined. The same approach, processes and care that are taken when examining the curriculum guidelines are applied.

The examination turns out a challenging scenario that the skills frameworks vary significantly, which makes their comparisons not sense-making or even impossible. A choice of a framework is made to proceed the study. Then the professional practice competencies specified in this framework (SFIA 7) are compared with the curricular competencies, exposing the gaps [8].

\section{KEY CONCEPTS: DATA ANALYTICS AND COMPETENCY}

Data analytics as an IT skillset becomes an asset in the forms of infrastructure, human resources and the associated intangibles such as tacit knowledge and culture. It becomes an asset to the extent that it is employed and utilized by an organization [6].

The value of data analytics comes primarily from its capability and usefulness to make out from Big Data. "Big data is a term that is used to describe data that is high volume, high velocity, and/or high variety; requires new technologies and techniques to capture, store, and analyze it; and is used to enhance decision making, provide insight and discovery, and support and optimize processes." [25].

Data analytics is seen to have gone through three genealogical phases: decision support systems (DSS) in 1970's, business intelligence (BI) in 1990's, and data analytics in 2010's [5, 25]. It is a persisting skillset involving "getting data in" to a data mart or warehouse and "getting data out" from the data that is stored. It is important to train future data scientists with the corresponding programming and analytical skills [11]. With Big Data there are three general types of analysis: descriptive, predictive and prescriptive. The descriptive summarizes what happened in the past, the predictive suggests what will happen in the future, and the prescriptive tells what to do. Different algorithms, mainly statistical, are used, with data mining, machine learning and neutral networks at the high end.

The three V's (volume, velocity and variety) to identify Big Data was later extended to seven by [21]. They added variability, veracity, visualization and value as new dimensions. This conception has not been adopted in MSIS 2016, IT2017 and IS2020 so far. A newer perspective is to see data analytics in a lifecycle involving data management, data preprocessing and integration through data modelling and business intelligence to insight management [16]. The spectrum of big data analytics should be further identified to include data mining, machine learning, data science and systems, and its relations to artificial intelligence, distributed computing and systems, and cloud computing, taking into account technical aspects [22]. Again, this perspective is yet to be assessed for adoption to the guidelines.

Competency, in IT2008 and IS2010, is conceived as a body of knowledge, content and learning outcomes [10, 23]. This conception facilitates curriculum design, but is seen less reflecting the demand of the IT job market. It is therefore replaced by the triadic model which is expressed as "Competency = Knowledge + Skills + Dispositions" in IT2017 and IS2020.

A newer conception of competency is proposed by [17], namely, a holistic model expressed as "Competency = functional competence + cognitive competence + social competence + meta competence". The functional refers to the ability to perform a range of activities, achieve specific outcomes and demonstrate industry standards. The cognitive is the ability to think and act in an insightful way to solve problems, including using tacit, practical and contextualized knowledge. The social is the ability to cooperate with others and the meta-competence, the ability to cope with uncertainty, self-learning, reflection and adaptation [11].

Although framed differently, the holistic model covers the same scope and content of IT competencies as does the triadic model. It emphasizes on ability which corresponds largely to the skills in the triadic model and for this reason, this study prioritizes ability and skills as working concepts to understand and identify technical competencies.

\section{THREE CURRICULUM GUIDELINES}

MSIS2016, IT2017 and IS2020 are three well-distributed IT and IS curriculum guidelines that are published by ACM, AIS and IEEE CS (two of them for each publication). They provide a broad landscaping and taxonomic mapping of the computing domains. MSIS2016, IT2017 and IS2020 stand for Global Competency Model for Graduate Degree Programs in Information Systems, Information Technology Curricula 2017, and A Competency Model for Undergraduate Programs in Information Systems respectively.

MSIS2016 [1] is related to postgraduate programs. It identifies nine IS competency areas, one of which is Data, Information and Content Management. Under each area are 
competency categories and under each category are actual competencies. An actual competency is then assigned with one of the four attainment levels including Awareness, Novice, Supporting (role), and Independent (contributor). Awareness refers to knowledge and understanding at general level. Novice indicates the ability to communicate effectively and perform essential activities under supervision. Supporting refers to the ability to collaborate with others to achieve desired outcomes, and Independent demonstrates the ability to perform complex tasks without supervision.

Data analytics as a skillset is integrated into the competency are of Data, Information and Content Management. In this area there are five relevant data analytics competencies predominately at Novice level, as shown Table I.

\section{TABLE I. DATA ANALYTICS ATTAINMENT LEVELS UNDER MSIS2016}

\begin{tabular}{|c|c|c|}
\hline \multicolumn{1}{|c|}{ Competencies } & $\begin{array}{c}\text { Identifier } \\
\text { Words }\end{array}$ & $\begin{array}{c}\text { Levels of } \\
\text { Attainment }\end{array}$ \\
\hline $\begin{array}{c}\text { Selecting appropriate data } \\
\text { management technologies based on } \\
\text { the needs of the domain }\end{array}$ & $\begin{array}{c}\text { Unstructured } \\
\text { data } \\
\text { Designing and implementing a data } \\
\text { warehouse using a contemporary } \\
\text { architectural solution }\end{array}$ & $\begin{array}{c}\text { Supporting } \\
\text { (role) }\end{array}$ \\
\hline $\begin{array}{c}\text { Integrating and preparing data } \\
\text { captured from various sources for } \\
\text { analytical use }\end{array}$ & $\begin{array}{c}\text { Multiple data } \\
\text { types }\end{array}$ & Novice \\
\hline $\begin{array}{c}\text { Selecting and using appropriate } \\
\text { analytics methods }\end{array}$ & $\begin{array}{c}\text { Analytics } \\
\text { methods }\end{array}$ & Novice \\
\hline $\begin{array}{c}\text { Analyzing data using advanced } \\
\text { contemporary methods }\end{array}$ & $\begin{array}{c}\text { Identify } \\
\text { patterns }\end{array}$ & Novice \\
\hline
\end{tabular}

IT2017 [3] addresses competencies in three IT domains: essential, supplemental and intermediate (overlapping essential and supplemental). The essential identifies the minimal competencies that must be obtained for an IT degree. The supplemental indicates competencies for more specialized work such as cloud computing and IoTs. Each competency is assigned with one of the three levels of learning engagement, namely, L1, L2 and L3. L1 indicates the minimal degree of engagement associating with fundamentals learning, L2 denotes a large degree of engagement associating with applications in complex problems and situations, and L3 refers to more time-intensive evaluations that require in-depth and personalized feedback and possibly employers' input.

Data analytics, together with scalability, is identified as a supplemental domain. Five competencies are further identified and they are predominately at Level 2 as shown in following table.

\section{TABLE II. DATA ANALYTICS LEVELS OF} LEARNING ENGAGEMENT UNDER IT2017

\begin{tabular}{|c|c|}
\hline Competencies & $\begin{array}{c}\text { Levels of } \\
\text { learning } \\
\text { engagement }\end{array}$ \\
\hline $\begin{array}{c}\text { Using appropriate data analysis methods to solve real- } \\
\text { world problems }\end{array}$ & 2 \\
\hline $\begin{array}{c}\text { Performing data preprocessing techniques-data } \\
\text { integration, data cleansing, data transformation, and data }\end{array}$ & 2 \\
\hline
\end{tabular}

reduction to clean and prepare data sets for analysis

Using big data platforms including but not limited to Hadoop, Spark, and tools including but not limited to $\mathrm{R}$ and RStudio, MapReduce and SAS to analyze data in different application domains

Use data-intensive computations and streaming analytics on cluster and cloud infrastructures to drive better organization decisions

Examine the impact of large-scale data analytics on organization performance using case studies

Using appropriate data analysis methods to solve realworld problems

IS2020 [2] uses a matrix of six realms and two layers to identify competencies. The realms are used to identify the general IS domains and the layers, distinguish required from elective competencies. The required are the core for IS programs and the elective, the optional that are built upon the core. Each competency is identified as a knowledge-skill pair and each pair is assigned with one of the six Bloom cognitive levels. Data analytics is in the realm of Data and Information Management as an elective. Table III shows its seven competencies and where they are at the Bloom cognitive levels.

TABLE III. DATA ANALYTICS COMPETENCIES AND THEIR BLOOM COGNITIVE LEVELS UNDER IS2020

\begin{tabular}{|c|c|c|}
\hline Competencies & $\begin{array}{c}\text { Bloo } \\
\text { m } \\
\text { cognitive } \\
\text { levels }\end{array}$ & $\begin{array}{c}\text { Bloom } \\
\text { keywords }\end{array}$ \\
\hline $\begin{array}{c}\text { Applying the principles of computational } \\
\text { thinking (CT) to learning data science }\end{array}$ & 2,4 & $\begin{array}{c}\text { Understand, } \\
\text { analyse }\end{array}$ \\
\hline $\begin{array}{c}\text { Analyzing data science problems with a } \\
\text { CT framework }\end{array}$ & 2,3 & $\begin{array}{c}\text { Understand, } \\
\text { apply }\end{array}$ \\
\hline $\begin{array}{c}\text { Expressing a business problem as a data } \\
\text { problem }\end{array}$ & 2,5 & $\begin{array}{c}\text { Understand, } \\
\text { evaluate }\end{array}$ \\
\hline $\begin{array}{c}\text { Performing exploratory data analysis } \\
\text { from inception to the value proposition }\end{array}$ & 3,6 & Apply, create \\
\hline $\begin{array}{c}\text { Explaining the core principles behind } \\
\text { various analytics tasks such as } \\
\text { classification, clustering, optimization, } \\
\text { recommendation }\end{array}$ & 4 & Analyse \\
\hline $\begin{array}{c}\text { Articulating the nature and potential of } \\
\text { Big Data }\end{array}$ & 2 & Understand \\
\hline $\begin{array}{c}\text { Demonstrating the use of big data tools } \\
\text { on real world case-studies }\end{array}$ & 5 & Evaluate \\
\hline
\end{tabular}

As shown in Table IV on the next page, a comparison between IS undergraduate and postgraduate programs reveals that:

1) The undergraduate programs have a foundational part which is focused on principles, conceptions and understanding (data problems).

2) The postgraduate programs have an extension that covers a supporting (role) in selecting data management technologies, designing and implementing data warehouses.

3) In the processes to solve data analytics problems, the two programs share the ability to apply essential skills and principles, however the graduate programs have more engagement with using wider data sources and contemporary methods. 


\begin{tabular}{|c|c|c|}
\hline \begin{tabular}{l}
\multicolumn{1}{c}{ IS2020 } \\
- Applying the \\
principles of \\
computational \\
thinking $(\mathrm{CT})$ to \\
learning data science \\
- Analyzing data \\
science problems \\
with a CT framework \\
- Expressing a business \\
problem as a data \\
problem
\end{tabular} & MISI2016 & $\begin{array}{c}\text { Comparison } \\
\text { Foundational: } \\
\circ \text { Principles and } \\
\text { conceptions } \\
\circ \text { Understanding of } \\
\text { data problems }\end{array}$ \\
\hline $\begin{array}{l}\text { - Performing } \\
\text { exploratory data } \\
\text { analysis from } \\
\text { inception to the value } \\
\text { proposition } \\
\text { - Explaining the core } \\
\text { principles behind } \\
\text { various analytics } \\
\text { tasks such as } \\
\text { classification, } \\
\text { clustering, } \\
\text { optimization, } \\
\text { recommendation } \\
\text { - Articulating the } \\
\text { nature and potential } \\
\text { of Big Data } \\
\text { - Demonstrating the } \\
\text { use of big data tools } \\
\text { on real world case- } \\
\text { studies }\end{array}$ & $\begin{array}{l}\text { - Integrating and } \\
\text { preparing data } \\
\text { captured from } \\
\text { various sources } \\
\text { for analytical } \\
\text { use } \\
\text { - Selecting and } \\
\text { using } \\
\text { appropriate } \\
\text { analytics } \\
\text { methods } \\
\text { - Analyzing data } \\
\text { using advanced } \\
\text { contemporary } \\
\text { methods }\end{array}$ & $\begin{array}{l}\text { - Common: } \\
\text { ○ Application of } \\
\text { principles and } \\
\text { essential skills in } \\
\text { problem-solving } \\
\text { - Different: } \\
\text { ○ Narrower vs wider } \\
\text { data sources } \\
\text { ○ Essential vs } \\
\text { contemporary } \\
\text { methods }\end{array}$ \\
\hline & $\begin{array}{l}\text { - Selecting } \\
\text { appropriate data } \\
\text { management } \\
\text { technologies } \\
\text { based on the } \\
\text { needs of the } \\
\text { domain } \\
\text { - Designing and } \\
\text { implementing a } \\
\text { data warehouse } \\
\text { using a } \\
\text { contemporary } \\
\text { architectural } \\
\text { solution }\end{array}$ & $\begin{array}{l}\text { - Extensional: } \\
\circ \text { Selection of data } \\
\text { management } \\
\text { technologies } \\
\circ \text { Design and } \\
\text { implementation of } \\
\text { data warehouse }\end{array}$ \\
\hline
\end{tabular}

Table V shows the results of a comparison between IS2020 and IT2017, suggesting:

1) The IT and IS undergraduate programs share the same scope in the data analytics domain.

2) IS programs have more engagement with knowledge and understanding applications whilst IT programs, processing and skills applications.

3) Systems and software such as Hadoop, R and SAS are specified for IT programs to ensure coverage and complexity in applying technologies.

\section{TABLE V. COMPARISON BETWEEN IS AND IT UNDERGRADUATE PROGRAMS FOR DATA ANALYTICS COMPETENCIES}

\begin{tabular}{|c|c|c|}
\hline IS2020 & IT2017 & Comparison \\
\hline $\begin{array}{l}\text { - Applying the } \\
\text { principles of } \\
\text { computational } \\
\text { thinking (CT) to } \\
\text { learning data } \\
\text { science } \\
\text { - Analyzing data } \\
\text { science problems } \\
\text { with a CT } \\
\text { framework } \\
\text { - Expressing a } \\
\text { business problem as } \\
\text { a data problem } \\
\text { - Performing } \\
\text { exploratory data } \\
\text { analysis from } \\
\text { inception to the } \\
\text { value proposition } \\
\text { - Explaining the core } \\
\text { principles behind } \\
\text { various analytics } \\
\text { tasks such as } \\
\text { classification, } \\
\text { clustering, } \\
\text { optimization, } \\
\text { recommendation } \\
\text { - Articulating the } \\
\text { nature and potential } \\
\text { of Big Data } \\
\text { - Demonstrating the } \\
\text { use of big data tools } \\
\text { on real world case- } \\
\text { studies }\end{array}$ & $\begin{array}{l}\text { - Using appropriate } \\
\text { data analysis } \\
\text { methods to solve } \\
\text { real-world } \\
\text { problems } \\
\text { - Performing data } \\
\text { preprocessing } \\
\text { techniques -data } \\
\text { integration, data } \\
\text { cleansing, data } \\
\text { transformation, } \\
\text { and data reduction } \\
\text { to clean and } \\
\text { prepare data sets } \\
\text { for analysis } \\
\text { - Using big data } \\
\text { platforms such as } \\
\text { Hadoop, Spark, } \\
\text { and tools including } \\
\text { R, RStudio, } \\
\text { MapReduce and } \\
\text { SAS to analyze } \\
\text { data in different } \\
\text { application } \\
\text { domains } \\
\text { - Use data-intensive } \\
\text { computations and } \\
\text { streaming analytics } \\
\text { on cluster and } \\
\text { cloud } \\
\text { infrastructures to } \\
\text { drive better } \\
\text { organization } \\
\text { decisions } \\
\text { - Examine the } \\
\text { impact of large- } \\
\text { scale data analytics } \\
\text { on organization } \\
\text { performance using } \\
\text { case studies } \\
\text { - Using appropriate } \\
\text { data analysis } \\
\text { methods to solve } \\
\text { real-world } \\
\text { problems }\end{array}$ & $\begin{array}{l}\text { - Common: } \\
\text { ○ Scope of domain } \\
\text { - Different: } \\
\text { ○ Knowledge vs } \\
\text { skills applications } \\
\circ \text { Understanding vs } \\
\text { processing } \\
\text { ○ Unspecified vs } \\
\text { specified software } \\
\text { engagement }\end{array}$ \\
\hline
\end{tabular}

\section{THREE SKILLS FRAMEWORKS}

SFIA 7, e-CF 3.0 and SF for ICT are three industry skills frameworks that are used by IT practitioners, employers and IT professional bodies such as UKAS (the U.K.), ACS (Australia) and IT Professionals (New Zealand) for IT accreditations and certifications. They are used in this study to check and identify gaps in curricular competencies. SFIA 7, e-CF 3.0 and SF for ICT stand for Skills Framework for the Information Age (version 7), European e-Competence Framework (version 3.0), and Skills Frameworks for ICT respectively.

SFIA is a UK-based framework [20]. It identifies competencies in a matrix of 102 professional skills and seven levels of responsibilities. This matrix is highly differentiating to enhance pertinence and accuracy for competency identification, composition and application. 
The seven levels of responsibility, namely, Follow, Assist, Apply, Enable, Ensure and Advise, Initiate and Influence, Set Strategies, Inspire and Mobilize, are used to further identify each competency. Data analytics is identified as a cluster of skills, as shown in Table VI.

TABLE VI. DATA ANALYTICS COMPETENCIES, LEVELS AND FOCUSES OF RESPONSIBILITY UNDER SFIA 7

\begin{tabular}{|c|c|c|c|}
\hline Competencies & $\begin{array}{c}\text { Levels of } \\
\text { Responsibility }\end{array}$ & $\begin{array}{c}\text { Focuses of Responsibility } \\
\text { (In typical tasks) }\end{array}$ & Detailed Descriptions \\
\hline $\begin{array}{l}\text { - Applying mathematics, statistics, } \\
\text { predictive modeling and machine-learning } \\
\text { techniques to discover meaningful patterns } \\
\text { and knowledge in recorded data }\end{array}$ & 3 & $\begin{array}{c}\text { Apply } \\
\text { (Perform a range of work } \\
\text { under specific direction) }\end{array}$ & $\begin{array}{l}\text { - Undertaking analytical activities and delivers analysis } \\
\text { outputs, in accordance with customer needs and } \\
\text { conforming to agreed standards }\end{array}$ \\
\hline $\begin{array}{l}\text { - Analyzing data with high volumes, } \\
\text { velocities and variety (numbers, symbols, } \\
\text { text, sound and image) }\end{array}$ & 4 & $\begin{array}{c}\text { Enable } \\
\text { (Perform a range of } \\
\text { complex work under general } \\
\text { direction) }\end{array}$ & $\begin{array}{l}\text { - Applying a range of mathematical, statistical, } \\
\text { predictive modelling or machine-learning techniques } \\
\text { in consultation with experts if appropriate, and with } \\
\text { sensitivity to the limitations of the techniques } \\
\text { - Selecting, acquiring and integrating data for analysis } \\
\text { - Developing data hypotheses and methods, training } \\
\text { and evaluating analytics models, sharing insights and } \\
\text { findings and continuing to iterate with additional data }\end{array}$ \\
\hline $\begin{array}{l}\text { Developing forward-looking, predictive, } \\
\text { real-time, model-based insights to create } \\
\text { value and drive effective decision-making }\end{array}$ & 5 & $\begin{array}{c}\text { Ensure and advise } \\
\text { (Perform an extensive } \\
\text { range of complex and self- } \\
\text { initiated work under broad } \\
\text { direction) }\end{array}$ & $\begin{array}{l}\text { - Evaluating the need for analytics, assesses the } \\
\text { problems to be solved and what internal or external } \\
\text { data sources to use or acquire } \\
\text { - Specifying and applying appropriate mathematical, } \\
\text { statistical, predictive modelling or machine-learning } \\
\text { techniques to analyze data, generate insights, create } \\
\text { value and support decision-making } \\
\text { - Managing reviews of the benefits and value of } \\
\text { analytics techniques and tools and recommends } \\
\text { improvements } \\
\text { - Contributing to the development of analytics policy, } \\
\text { standards and guidelines }\end{array}$ \\
\hline \multirow[t]{2}{*}{$\begin{array}{l}\text { - Identifying, validating and exploiting } \\
\text { internal and external data sets generated } \\
\text { from a diverse range of processes }\end{array}$} & 6 & $\begin{array}{c}\text { Initiate and influence } \\
\text { (Perform highly complex } \\
\text { work involving technical, } \\
\text { financial and quality aspects) }\end{array}$ & $\begin{array}{l}\text { - Developing analytics policy, standards and guidelines } \\
\text { - Establishing and managing analytics methods, } \\
\text { techniques and capabilities to enable the organization } \\
\text { to analyze data, to generate insights, create value and } \\
\text { drive decision-making } \\
\text { - Setting direction and leads the introduction and use of } \\
\text { analytics to meet overall business requirements, } \\
\text { ensuring consistency across all user groups } \\
\text { - Identifying and establishing the veracity of the } \\
\text { external sources of information which are relevant to } \\
\text { the operational needs of the enterprise }\end{array}$ \\
\hline & 7 & $\begin{array}{l}\text { Set strategy, inspire and } \\
\quad \text { mobilise } \\
\text { (Lead on formulating and } \\
\text { implementing strategy) }\end{array}$ & $\begin{array}{l}\text { - Directing the creation and review of a cross- } \\
\text { functional, enterprise-wide approach and culture for } \\
\text { analytics } \\
\text { - Leading the provision of the organization's analytics } \\
\text { capabilities. } \\
\text { - Leading the organization's commitment to efficient } \\
\text { and effective analysis of textual, numerical, visual or } \\
\text { audio information }\end{array}$ \\
\hline
\end{tabular}

e-CF 3.0 is an EU-based framework [12]. It identifies 40 competencies in four dimensions (D1 to D4). D1 identifies five competency areas (ICT processes) including Plan, Build, Run, Enable and Manage. D2 provides a set of competencies for each area. D3 assigns each competency with one of the five proficiency levels (mapping EQF levels). EQF stands for European Qualifications Authority. D4 clarifies each set of competencies with exemplar knowledge and skills.
Data analytics is not identified as a separate competency but a component integrated in the competency set of Information and Knowledge Management. It is under the Enable umbrella.

Three proficiency levels are assigned to the competency set rather than to data analytics, leaving an ambiguity. Table VII shows how the competency set is identified. 
TABLE VII. DATA ANALYTICS COMPETENCY SET, PROFICIENCY, EXEMPLAR KNOWLEDGE AND SKILLS UNDER E-CF 3.0

\begin{tabular}{|l|c|c|c|}
\hline \multicolumn{1}{|c|}{$\begin{array}{c}\text { Competency set } \\
\text { (Incl. data analytics) }\end{array}$} & $\begin{array}{c}\text { Levels of Proficiency } \\
\text { (In typical tasks) }\end{array}$ & $\begin{array}{c}\text { Knowledge } \\
\text { (Exemplar) }\end{array}$ & \multicolumn{1}{|c|}{ Skills } \\
(Exemplar)
\end{tabular}

SF for ICT is a Singapore-based framework [4]. IMDA and SSG stand for Infocomm Media Development Authority and Skills-Future Singapore respectively. SF covers 104 job roles that comprise 80 technical and 18 generic competencies. The technical competencies are categorized into seven tracks and 32 sub-tracks to acknowledge career pathways. Each sub-track is identified with a line of job roles, critical work functions, key tasks and associated specific skills and competencies. Levels of proficiency are indicated but their source is not found in the framework document. Data analytics is identified and it is unclear whether it is a skill, a competency, or their combination, as skills and competencies are presented in concatenations. The track is Business Intelligence which is shared by job roles involving both data analyst and data engineer at a lower level. Table VIII shows how data analytics is shared by different jobs.

\section{TABLE VIII. DATA ANALYTICS TASKS IN JOBS}

\begin{tabular}{|c|c|c|}
\hline Data Analytics & $\begin{array}{r}\text { Levels of } \\
\text { Proficiency }\end{array}$ & Job Roles \\
\hline $\begin{array}{l}\text { - Identifying underlying trends and } \\
\text { patterns in business data using } \\
\text { statistical and computational } \\
\text { techniques and tools }\end{array}$ & 2 & $\begin{array}{l}\text { - Data analyst } \\
\text { - Associate } \\
\text { data engineer }\end{array}$ \\
\hline $\begin{array}{l}\text { - Developing, applying and evaluating } \\
\text { algorithms, predictive data } \\
\text { modelling and data visualization to } \\
\text { identify trends and patterns in data }\end{array}$ & 3 & $\begin{array}{l}\text { - Data analyst } \\
\text { - Associate } \\
\text { data engineer }\end{array}$ \\
\hline $\begin{array}{l}\text { - Designing and conducting data } \\
\text { studies to drive organizational } \\
\text { decisions and insights }\end{array}$ & 4 & $\begin{array}{l}\text { - Business } \\
\text { intelligence } \\
\text { manager } \\
\end{array}$ \\
\hline $\begin{array}{l}\text { - Managing and enhancing } \\
\text { organizational data science } \\
\text { capability by refining financial and } \\
\text { other business performance criteria } \\
\text { and design data studies }\end{array}$ & 5 & $\begin{array}{l}\text { - Business } \\
\text { intelligence } \\
\text { director }\end{array}$ \\
\hline
\end{tabular}

Table IX on the right shows key tasks of an exemplar role (the case of data analyst):

\section{TABLE IX. KEY TASKS OF AN EXEMPLAR ROLE (FOR} THE DATA ANALYST)

\begin{tabular}{|c|c|c|c|}
\hline $\begin{array}{l}\text { Critical } \\
\text { work } \\
\text { functions }\end{array}$ & $\begin{array}{c}\text { Identify } \\
\text { business needs }\end{array}$ & $\begin{array}{l}\text { Prepare and } \\
\text { analyse data }\end{array}$ & $\begin{array}{l}\text { Present } \\
\text { insight }\end{array}$ \\
\hline $\begin{array}{r}\text { Data } \\
\text { Analyst }\end{array}$ & $\begin{array}{l}\text { - Identify } \\
\text { information } \\
\text { needs of } \\
\text { stakeholders } \\
\text { required for } \\
\text { decision- } \\
\text { making } \\
\text { - Assist in the } \\
\text { transaction of } \\
\text { business } \\
\text { needs into } \\
\text { analytics and } \\
\text { reporting } \\
\text { requirements } \\
\text { - Recommend } \\
\text { types of data } \\
\text { and data } \\
\text { sources } \\
\text { needed to } \\
\text { obtain the } \\
\text { required } \\
\text { information } \\
\text { and insights } \\
\text { - Assist in } \\
\text { identifying } \\
\text { potential } \\
\text { business } \\
\text { intelligence } \\
\text { service } \\
\text { offerings } \\
\text { required by } \\
\text { the business }\end{array}$ & $\begin{array}{l}\text { - Gather data from } \\
\text { internal systems } \\
\text { and external } \\
\text { resources } \\
\text { - Perform data } \\
\text { entry tasks in } \\
\text { data collection } \\
\text { systems } \\
\text { - Clean and update } \\
\text { databases to } \\
\text { remove } \\
\text { duplicated, } \\
\text { outdated or } \\
\text { irrelevant } \\
\text { information } \\
\text { - Perform data } \\
\text { validation and } \\
\text { quality control } \\
\text { checks } \\
\text { - Perform basic } \\
\text { extract, transform } \\
\text { and load related } \\
\text { activities to } \\
\text { prepare data for } \\
\text { analysis or } \\
\text { transfer } \\
\text { - Analyze data to } \\
\text { identify trends, } \\
\text { patterns and } \\
\text { correlations to } \\
\text { support decision- } \\
\text { making } \\
\text { - Propose solutions } \\
\text { and } \\
\text { recommendations } \\
\text { to address } \\
\text { information } \\
\text { needs }\end{array}$ & $\begin{array}{l}\text { - Develop } \\
\text { automated and } \\
\text { logical data } \\
\text { models and } \\
\text { data output } \\
\text { models } \\
\text { - Translate } \\
\text { analysis into } \\
\text { common } \\
\text { business } \\
\text { language to } \\
\text { influence } \\
\text { business } \\
\text { decisions or } \\
\text { actions } \\
\text { - Design data } \\
\text { reports and } \\
\text { visualization } \\
\text { tools to } \\
\text { facilitate data } \\
\text { understanding } \\
\text { through } \\
\text { storytelling }\end{array}$ \\
\hline
\end{tabular}


SFIA 7, e-CF 3.0 and SF for ICT are built with different perspectives, focuses, intersections and dimensions. Data analytics is identified variedly and in cases ambiguous and intricate. It can be a cluster of skills, a competency or a component that is combined with others to serve larger competencies. Give the big differences, reducing analysis of them to comparisons may not be appropriate nor even possible. To proceed the analysis, a framework must be chosen.

SFIA 7 is chosen for it is the best fit-for-purpose choice. The purpose is ultimately to inform curriculum designs, reviews and revisions. As compared with the other two, SFIA 7 is seen to have provided a set of competencies that best match the competencies derived from IS2020, MISI2016 and IT2017 in scope, content and abstraction (categorization), which enables a comparative analysis. SFIA 7 also provides a clearer basis for assigning proficiency levels.

As shown Table X, a comparison between SFIA 7 and each of the curriculum guidelines yields the following outcomes.
1) Each of IS and IT undergraduate programs covers the same scope of domain as SFIA 7. IS postgraduate programs cover more, however the same core.

2) Both IS programs focus on understanding and analysis of problems rather than performing tasks to solutions. They also focus on knowledge rather than skills applications.

3) Undergraduate programs in IS appear short in engagement with AI (machine learning) and Big Data (in sources and formats).

4) IT undergraduate programs appear short in engagement with AI (machine learning), but not short with traditional systems and software (coverage and complexity).

5) Postgraduate programs in IS typify senior roles, covering a scope wider than the norm scope in professional practice.

In general, the professional practice competencies are largely or predominately satisfied by IS and IT programs. However, all the programs have more or less gaps to fill.

\section{TABLE X. COMPARISONS BETWEEN SFIA 7 VS IS2020, MISI2016 AND IT2017 IN THE COMPETENCIES}

\begin{tabular}{|c|c|c|}
\hline SFIA7 & IS2020 & Comparison \\
\hline \multirow{2}{*}{$\begin{array}{l}\text { - Applying mathematics, statistics, predictive } \\
\text { modeling and machine-learning techniques to } \\
\text { discover meaningful patterns and knowledge } \\
\text { in recorded data } \\
\text { - Analyzing data with high volumes, velocities } \\
\text { and variety (numbers, symbols, text, sound } \\
\text { and image) } \\
\text { - Developing forward-looking, predictive, real- } \\
\text { time, model-based insights to create value and } \\
\text { drive effective decision-making } \\
\text { - Identifying, validating and exploiting internal } \\
\text { and external data sets generated from a diverse } \\
\text { range of processes }\end{array}$} & \multirow{2}{*}{$\begin{array}{l}\text { - Applying the principles of computational thinking (CT) to } \\
\text { learning data science } \\
\text { - Analyzing data science problems with a CT framework } \\
\text { - Expressing a business problem as a data problem } \\
\text { - Performing exploratory data analysis from inception to the } \\
\text { value proposition } \\
\text { - Explaining the core principles behind various analytics } \\
\text { tasks such as classification, clustering, optimization, } \\
\text { recommendation } \\
\text { - Articulating the nature and potential of Big Data } \\
\text { Demonstrating the use of big data tools on real world } \\
\text { case-studies }\end{array}$} & $\begin{array}{l}\text { Common: } \\
\text { o Scope of domain }\end{array}$ \\
\hline & & $\begin{array}{l}\text { - Different: } \\
\text { ○ Performing vs understanding and } \\
\text { analysis } \\
\circ \text { Skills vs knowledge applications } \\
\circ \text { Specified vs unspecified AI (machine } \\
\text { learning) applications } \\
\text { O Specified vs unspecified Big Data } \\
\text { involvements }\end{array}$ \\
\hline SFIA7 & MISI2016 & Comparison \\
\hline $\begin{array}{l}\text { - Applying mathematics, statistics, predictive } \\
\text { modeling and machine-learning techniques to } \\
\text { discover meaningful patterns and knowledge } \\
\text { in recorded data } \\
\text { - Analyzing data with high volumes, velocities } \\
\text { and variety (numbers, symbols, text, sound } \\
\text { and image) } \\
\text { - Developing forward-looking, predictive, real- } \\
\text { time, model-based insights to create value and } \\
\text { drive effective decision-making } \\
\text { - Identifying, validating and exploiting internal } \\
\text { and external data sets generated from a diverse } \\
\text { range of processes }\end{array}$ & $\begin{array}{l}\text { - Integrating and preparing data captured from various } \\
\text { sources for analytical use } \\
\text { - Selecting and using appropriate analytics methods } \\
\text { - Analyzing data using advanced contemporary methods } \\
\text { - Selecting appropriate data management technologies } \\
\text { based on the needs of the domain } \\
\text { - Designing and implementing a data warehouse using a } \\
\text { contemporary architectural solution }\end{array}$ & $\begin{array}{l}\text { - Common: } \\
\text { o Core scope of domain } \\
\text { - Different: } \\
\text { o Performing vs understanding and } \\
\text { analysis } \\
\text { O Skills vs knowledge applications } \\
\text { O Narrower vs wider scopes } \\
\text { (involvement of data warehouse and } \\
\text { management technology) }\end{array}$ \\
\hline SFIA7 & IT2017 & Comparison \\
\hline $\begin{array}{l}\text { - Applying mathematics, statistics, predictive } \\
\text { modeling and machine-learning techniques to } \\
\text { discover patterns and knowledge in data } \\
\text { - Analyzing data with high volumes, velocities, } \\
\text { variety (numbers, symbols, text, sound, image) } \\
\text { - Developing forward-looking, predictive, real- } \\
\text { time, model-based insights to create value and } \\
\text { drive effective decision-making }\end{array}$ & $\begin{array}{l}\text { - Using data analysis methods to solve real-world problems } \\
\text { - Performing data preprocessing techniques - data } \\
\text { integration, data cleansing, data transformation, and data } \\
\text { reduction to clean and prepare data sets for analysis } \\
\text { - Using big data platforms including but not limited to } \\
\text { Hadoop, Spark, and tools including but not limited to R } \\
\text { and RStudio, MapReduce and SAS to analyze data in } \\
\text { different application domains }\end{array}$ & $\begin{array}{l}\text { - Common } \\
\text { o Scope of domain } \\
\text { - Different: } \\
\text { O Specified vs unspecified AI (machine } \\
\text { learning) applications } \\
\text { Onspecified vs specified software } \\
\text { engagements }\end{array}$ \\
\hline
\end{tabular}




\begin{tabular}{|l|l|l|}
\hline \multicolumn{1}{|c|}{ SFIA7 } & \multicolumn{1}{|c|}{ IS2020 } & \multicolumn{1}{c|}{ Comparison } \\
\hline $\begin{array}{l}\text { - Identifying, validating and exploiting internal } \\
\text { and external data sets generated from a diverse } \\
\text { range of processes }\end{array}$ & $\begin{array}{l}\text { - Use data-intensive computations and streaming analytics } \\
\text { on cluster and cloud infrastructures to drive better } \\
\text { organization decisions } \\
\text { Examine the impact of large-scale data analytics on } \\
\text { organization performance using case studies } \\
\text { Using appropriate data analysis methods to solve real- } \\
\text { world problems }\end{array}$ & $\begin{array}{l}\text { O Narrower vs wider scopes (evaluation } \\
\text { of impact on organizations, } \\
\text { involvement with cloud } \\
\text { infrastructure) }\end{array}$ \\
& \\
\hline
\end{tabular}

\section{REFERENCES}

\section{RECOMMENDATIONS, LIMITATIONS AND FUTURE RESEARCH}

Appreciating the great potential values and benefits of the global computing curriculum guidelines, this study joins the efforts to facilitate their applications. Through a series of examinations and analysis of MISI2016, IT2017 and IS2020, the study discovered the curricular competencies for typical IT and IS programs in a case domain of data analytics. Furthermore, through invoking SFIA 7, e-CF 3.0 and SF for ICT and using SFIA 7 for comparison, the study revealed the gaps for the programs to focus on for enhancing competencybased curriculum and graduate employability. Based on the outcomes of the study, it is recommended that:

1) Designs, reviews and revisions of IS programs (undergraduate and postgraduate) should have a focus on competencies for performing tasks and skills applications.

2) A focus for IS undergraduate programs is on engagement with AI (artificial intelligence and machine learning) techniques and Big Data in various sources and formats.

3) For IS postgraduate programs, it would be beneficial to check if their scope can be narrowed to make space for incorporating more skills applications.

4) It would be beneficial for IT undergraduate programs to check if AI techniques including machine learning can be engaged more to meet the requirements in the industry.

Particular systems and software for AI techniques learning are not named in SFIA 7. However, in SFIA Beta 8, the newest version, key competencies including evaluating trained models, selecting examination metrics and tracing machine learning outcomes are specified. Advanced analytic techniques in the data science spectrum, including data/text mining, pattern matching, semantics analysis, sentiment analysis, network and cluster analysis, multivariate statistics and simulation, are also mentioned [20]. Systems and software that accommodate these competencies and techniques better should be considered in curriculum designs, reviews and revisions.

This study is limited in that the data sources are primarily the reports from the global IT educational and professional associations. They satisfy IT and IS curriculum designs, reviews and revisions at program level. For analysis of specific learning outcomes, assessment and other curricular components at course, unit or module levels, more studies in depth, such as examining the IT job market, would be much beneficial.
[1] ACM \& AIS. (2017). MSIS 2016 Global competency model for graduate degree programs in information systems. https://www.acm.org/binaries/content/assets/education/msis2016.pdf

[2] ACM \& AIS. (2021). A competency model for undergraduate programs in information systems. https://dl.acm.org/citation.cfm?id=3460863

[3] ACM \& IEEE-CS. (2017). Information technology curricula 2017. Curriculum guidelines for baccalaureate degree programs in information technology. https://dl.acm.org/citation.cfm?id=3173161

[4] IMDA \& SSG. (2017). Skills Framework for Infocomm Technology. Retrieved on 10 September 2021 from Skills Framework for ICT (imda.gov.sg).

[5] Batistič, S., \& Van Der Laken, P. (2019). History, evolution and future of big data and analytics: a bibliometric analysis of its relationship to performance in organisations. British Journal of Management, 30(2), 229-251.

[6] Bharadwaj, A. S. (2000). 'A resource-based perspective on information technology capability and firm performance: an empirical investigation', MIS Quarterly, 24, pp. 169-196.

[7] Brown, J. (2020). An examination of the Skills Framework for the Information Age (SFIA) version 7. International Journal of Information Management, 51, 102058.

[8] Brown, J., \& Parr, A. (2018). ICT skill frameworks: do they achieve their goals and users' expectations? Advanced Journal of Professional Practice, 1(2), 38-47.

[9] DPBOKTM Foundation. (2019). Digital Practitioner Body of KnowledgeTM https://www.opengroup.org/certifications/dpbok

[10] Ekstrom, J. J., \& Lunt, B. M. IT2008: Information Technology Model Curriculum. In Seventh LACCEI Latin American and Caribbean Conference for Engineering and Technology (LACCEI'2009) (pp. 2-5).

[11] Erturk, E., \& Jyoti, K. (2015). Perspectives on a Big Data application: What database engineers and IT students need to know. Engineering, Technology \& Applied Science Research, 5(5), 850-853.

[12] European e-Competence Framework. (2013). e-CF 3.0. http://ecompetences.eu/wp-content/uploads/2014/02/European-eCompetence-Framework-3.0_CEN_CWA_16234-1_2014.pdf

[13] Frezza, S., Clear, T., \& Clear, A. (2020, October). Unpacking Dispositions in the CC2020 Computing Curriculum Overview Report. In 2020 IEEE Frontiers in Education Conference (FIE) (pp. 1-8). IEEE.

[14] Ho, S. Y., \& Frampton, K. (2010). A competency model for the information technology workforce: Implications for training and selection. Communications of the Association for Information Systems, $27(1), 5$.

[15] Lawler, J., \& Molluzzo, J. C. (2015). A proposed concentration curriculum design for big data analytics for information systems students. Information Systems Education Journal, 13(1), 45.

[16] Lu, J. (2020). Data Analytics Research-Informed Teaching in a Digital Technologies Curriculum. INFORMS Transactions on Education, 20(2), 57-72.

[17] Persaud, A. (2020). Key competencies for big data analytics professions: a multimethod study. Information Technology \& People.

[18] Sabin, M., Impagliazzo, J., Alrumaih, H., Tang, C., \& Zhang, M. (2018). IT2017 Report: Implementing A Competency-Based Information Technology Program. In Proceedings of the 49th ACM Technical Symposium on Computer Science Education (pp. 1045-1046). 
[19] Sánchez, F., Soler, A., López, D., Martín, C., Ageno, A., Belanche, L., ... \& Marés, P. (2014). Developing professional skills at tertiary level: A model to integrate competencies across the curriculum. In 2014 IEEE Frontiers in Education Conference (FIE) Proceedings (pp. 1-9). IEEE.

[20] SFIA Foundation. (2020). SFIA. https://sfia-online.org/en

[21] Sivarajah, U., Kamal, M. M., Irani, Z., \& Weerakkody, V. (2017). Critical analysis of Big Data challenges and analytical methods. Journal of Business Research, 70, 263-286.

[22] Sun, Z., \& Huo, Y. (2021). The spectrum of big data analytics. Journal of Computer Information Systems, 61(2), 154-162.

[23] Topi, H. (2019). Reflections on the current state and future of information systems education. Journal of Information Systems Education, 30(1), 1.

[24] Waguespack, L., \& Babb, J. (2019). Toward visualizing computing curricula: The challenge of competency. Information Systems Education Journal, 17(4), 51.
[25] Watson, H. J. (2014). Update tutorial: Big Data analytics: Concepts, technology, and applications. Communications of the Association for Information Systems, 44(1), 21.

\section{AUTHORS’ BACKGROUND IN RELATION TO THIS TOPIC:}

1. Dr Guozhen Huang is a senior academic with experience in course development, curriculum review, and external moderation across business and information systems. He is a member of the experts group within the Tertiary Education Quality and Standards Agency (TEQSA) in Australia.

2. Dr Emre Erturk is an experienced academic, Senior Member of the global Association for Computing Machinery (ACM), and a contributing reviewer for the 2017 ACM/IEEE Report, Information Technology Curricula 2017. $\mathrm{He}$ is also an experienced online course developer, researcher, and has worked in the past within NZQA teams on new IT qualifications development. 